\title{
Government Euroscepticism and differentiated integration
}

\section{Thomas Winzen}

Department of Government, University of Essex, Colchester, United Kingdom

Thomas Winzen, University of Essex, Wivenhoe Park, Colchester CO4 3SQ, United Kingdom. Email: thomas.winzen@essex.ac.uk

Thomas Winzen is a Lecturer in Government at the Department of Government, University of Essex.

For comments, I am grateful to Christopher Wratil, the contributors to and editors of this special issue, and three anonymous reviewers. 


\section{Government Euroscepticism and differentiated integration}

It is common to consider mass politics and Eurosceptic politicization as "postfunctionalist" constraints that encourage differentiated European integration. This study argues that the relevance of Euroscepticism depends on who wins the domestic competition for government office. European mass politics are organized as delegation systems. These systems concentrate authority in the government and give little influence to parliaments and publics. If Eurosceptic parties reach the government, they will push for differentiation and even disintegration. If pro-EU parties succeed, uniform integration is likely to prevail. An empirical analysis of differentiated integration from the 1992 Maastricht Treaty to the 2016 Single Resolution Fund shows that only government Euroscepticism—rather than opposition, extra-parliamentary, or popular Euroscepticism—encourages differentiation. This study explains how uniform integration can prevail even in ostensibly Eurosceptic countries. It suggests that the impact of Eurosceptic politicization depends on party competition and is often more limited than might seem at first sight.

Keywords: Differentiated integration; Euroscepticism; party politics

\section{Introduction}

There is little doubt that European integration has become politicized. Moreover, politicization in Europe focuses on the boundaries and limits of the EU polity. It entails the contestation of EU authority and the pro-integration elite consensus of many member states more than, for instance, the direction of the Union's policy agenda. The reasons for this have received much attention (Hooghe and Marks 2009; Hutter et al. 2016). This study is about consequences. Does Eurosceptic politicization affect the development of European integration? Does it lead to an ever more differentiated or "looser" EU and even disintegration, as countries in which integration has become contested demand to roll-back EU authority? 
At first sight, it seems likely that Eurosceptic politicization should lead to greater differentiation in the EU. It is common to think of mass politics, parties, and ideology as "post-functionalist" constraints on European integration (Hooghe and Marks 2009). If Eurosceptic parties succeed in domestic politics, prevent treaty reforms and demand opt-outs, they trigger differentiation (Schimmelfennig et al. 2015). Yet, this is not the only possibility. Another outcome is that pro-EU parties win elections, form coalitions, and support uniform integration (see also Hodson and Puetter 2019). Both outcomes are possible and have implications for institutional choices in the EU.

The literature recognizes that politicization does not necessarily lead to differentiation. Some even argue that the EU remains 'astonishingly unified' (Hvidsten and Hovi 2014, 4). Yet, studies mainly offer European-level and "functionalist" reasons such as rigid rules for institutional change, the EU's technocratic character, or externalities (Hvidsten and Hovi 2014; Kölliker 2001; Schimmelfennig 2014). These arguments suggest an analytical division of labour of, on one hand, domestic and mass politics that account for differentiation and, on the other, European constraints that foster unity. In contrast, this study examines whether different forms of domestic politicization lead to differentiated or uniform integration.

This is of course not the first discussion of whether Eurosceptic parties and voters matter. Hooghe and Marks (2009) already argued that these actors have to find ways to influence governmental policy, and recent contributions claim that they might struggle to do so (Hodson and Puetter 2019; Schimmelfennig 2014). In particular, referendums might help the Eurosceptic cause. Eurosceptic citizens and competitors might also pressure other parties to change their policy positions (Meijers 2017). If these mechanisms fail popular Euroscepticism could still influence the government directly. Eurosceptic extra-parliamentary parties could exert pressure and Eurosceptic 
parliamentarians use parliamentary means to change European policy. Finally, Eurosceptic parties might manage to join governments. Which of these forms of Euroscepticism actually affects differentiated integration remains uncertain, however. This is what this study explores.

How should we think about the importance of these different forms of Euroscepticism? I explore the assumption that Euroscepticism only influences differentiated integration if Eurosceptic parties obtain government positions. The reason is that member states organize mass politics in systems of delegation. Such systems concentrate authority at the top, leaving little influence for other actors (Strøm 2000). This is a standard argument, but it is especially salient in the EU context. Eurosceptic parties are likely to face additional obstacles_-including mainstream efforts to avoid EU topics in elections and exclusion from coalitions — and make it into the government rarely (Hodson and Puetter 2019; Schimmelfennig 2014). As a result, uniform integration could persist even if countries seem candidates for national opt-outs because Eurosceptic actors persistently fail to reach governmental authority.

An empirical analysis of the conditions under which member states obtain optouts from EU policy regimes during intergovernmental negotiations lends credibility to these claims. The analysis covers all treaty reforms from the 1992 Maastricht Treaty to the Intergovernmental Agreement on the Single Resolution Fund adopted in 2016. The results indicate that Eurosceptic politicization encourages differentiated European integration by making national opt-outs more likely. However, the evidence is most consistent with the view that Euroscepticism only matters at the level of government. Opposition Euroscepticism, the presence of strongly Eurosceptic parties in parliament or in the electoral arena, or popular Euroscepticism alone do not influence the 
likelihood that member states obtain opt-outs in treaty reform negotiations. Even in the case of government Euroscepticism, the evidence is not unambiguous.

\section{From Eurosceptic politicization to ever looser Union?}

Examples in which Eurosceptic politicization appears to have led to differentiated integration and even disintegration are easy to find. British voters, mobilized by the Eurosceptic UK Independence Party and Eurosceptic politicians of the Conservative Party, voted to leave the EU in 2016. Countries with comparatively Eurosceptic voters and parties, such as Denmark and Sweden but also younger member states such as Poland have refused to take part in important EU regimes such as the Eurozone, the Area of Freedom, Security and Justice, or the Charter of Fundamental Rights.

Politicization can be a significant constraint on European integration and driver of differentiation.

The literature provides theoretical foundations for this view. It conceptualizes politicization as backlash against the transfer of authority to the EU (Hooghe and Marks 2009). This backlash is not inevitable but depends on the political units with which citizens identify and which they want "in control". The more, and the more exclusively, citizens identify with the nation rather than the EU, the more suspicious they are of integration. They perceive a mismatch between the scope of the jurisdiction that makes policy (the EU) and their preferred community (the nation). Eurosceptic politicization can be seen as a form of nationalism and source of resistance to the dilution of the unity between the nation and the location of political authority.

Scholars then explain differentiation in European integration with cross-national variation in Eurosceptic politicization (Schimmelfennig et al. 2015). When governments negotiate reforms of the EU treaties, gridlock can arise if selected governments, constrained by domestic politicization, reject a compromise. This is especially likely to 
happen in negotiations of sensitive core state policies (e.g. the currency, border management, or fiscal resources) (Genschel and Jachtenfuchs 2014). Moreover, Eurosceptic voters and parties are unlikely to appreciate bargaining tools of the EU such as package deals and side-payments. Their resistance to integration is principled rather than about policy and financial gains. Under these conditions, EU efforts to agree on a new treaty often require opt-outs from the most sensitive integration projects for the most reluctant member states, thus producing differentiation. ${ }^{1}$

This study contributes to understanding the conditions and limits of this mechanism. For the most part, these limits are to be found at the European level—in rigid rules and policy externalities. First, the literature highlights that rigid European rules make differentiation rarer than expected. It prevents countries from negotiating differentiated disintegration (i.e. the "repatriation" of EU authority) (Schimmelfennig 2018). Under existing treaty rules, disintegration requires approval from all countries, which is generally unlikely. One might think that, faced with opposition, a Eurosceptic country could threaten to leave completely. Yet, this threat only works if the other governments believe it and value the country staying. Both is unlikely. At least some countries will value uniform integration—e.g. the oft-cited "integrity" of the single market — higher and veto the repatriation of authority despite the exit threat. Moreover, at least some countries will not believe the threat given that leaving the EU is risky.

\footnotetext{
${ }^{1}$ A question is why a Eurosceptic country does not veto a treaty entirely rather than opt-out of one policy? Yet, EU treaties are packages that included policies—such as the the single market - that even Eurosceptic governments supported. Vetoing an entire treaty would prevent such consensual reforms. Moreover, even a Eurosceptic veto does not prevent differentiation if the remaining member states can develop a policy outside of the treaty framework, as was true for the Schengen Area and still is for the European Stability Mechanism and Fiscal Compact.
} 
They will expect the Eurosceptic government to back down or come back later and acquiesce to the EU's terms. In brief, under the current reform requirements, Euroscepticism leads to differentiated integration more than disintegration.

Second, scholars highlight that the fear of adverse policy externalities limits differentiation. Consider that differentiation concentrates on a subset of the EU's competences: core state policies. In contrast, the EU's market and regulatory policies have produced no treaty differentiation (Schimmelfennig and Winzen 2014) ${ }^{2}$, and become more uniformly integrated over time in legislation (Winzen 2016). This might be due to low salience. These policies might have eschewed the attention of Eurosceptic parties and voters. Yet, there is a second reason. Opt-outs from the EU's market, regulatory and agricultural policies are expected to have detrimental effects on outsiders including lost market access, trade diversion, and lost subsidies (Kölliker 2001). These externalities further explain why the EU remains more uniformly integrated than might otherwise be expected (e.g. Hvidsten and Hovi 2014).

However, are all limits of differentiated integration to be found at the European level? This study instead explores the relevance of domestic Eurosceptic politicization in greater detail. The literature on differentiated integration has adopted a rather structural view of this phenomenon. Whereas Eurosceptic governments have been found to encourage differentiation, the literature has otherwise focused on structural factorsthe share of citizens with exclusive identities, national wealth, or good governanceinstead of adopting a more nuanced view of Eurosceptic politicization (Schimmelfennig

\footnotetext{
${ }^{2}$ It should be noted that market, regulatory, and agricultural policies have given rise to transitional differentiation in the context of enlargement (Plümper and Schneider 2007). These cases of differentiation originate in distributional conflicts rather than politicization and fall outside of the scope of this study.
} 
2016; Winzen and Schimmelfennig 2016). That these structural factors translate into Euroscepticism in the electorate, parliament, and government, and then trigger differentiation has been assumed rather than analysed.

Some studies find a link between Euroscepticism and other outcomes such as voting by governments (Hagemann et al. 2017), loyalty in the European Parliament (Koop et al. 2018), and governmental rhetoric (Hobolt and Wratil this issue). Another analysis finds no effect of Euroscepticism on Council voting (Bailer et al. 2015). However, these studies typically do not distinguish the various domestic manifestations of Euroscepticism either.

\section{Politicization and decision-making authority along the chain of delegation}

The theoretical argument begins from the post-functionalist starting point that ideology and mass politics influence the institutional development of European integration (Hooghe and Marks 2009). As post-functionalist theory holds, these factors come into play if issues gain salience in the "mass arenas" of elections and parliaments compared to the "interest group arenas" of policy consultations and lobbying. This plausibly explains why differentiated integration has been limited to salient and politically contested core state policies (see also Genschel and Jachtenfuchs 2014). Studies in the post-functionalist framework also explain which citizens are Eurosceptic (Hooghe and Marks 2005), which parties adopt Eurosceptic programs (de Vries and Edwards 2009; de Vries and Hobolt 2012; Hutter et al. 2016), and the conditions under which these parties attract votes on this basis (de Vries 2007).

However, post-functionalist theory has been more explicit on the emergence of Eurosceptic voters and parties than the conditions under which they influence EU-level outcomes. Hooghe and Marks $(2009,18)$ plausibly argue that a 'reform may be blocked if Eurosceptical parties gain control of government ... or if a simple majority of the 
public of one or two countries votes 'No' in a referendum.' They leave open whether Eurosceptic actors also influence European reforms if they are not in the government or able to influence a referendum. This question also invites further thinking about the institutions of domestic politics. Whereas post-functionalism introduces an important distinction between the interest group and mass arena, the latter is left relatively underinstitutionalized as it is mainly conceptualized as the arena of mass politics and ideology. Yet, domestic political institutions allow Eurosceptic actors to exist at different levels such as in opposition or in the electorate. We should explore what this implies for their impact on political outcomes.

As a first step in thinking about the impact and limits of Eurosceptic politicization, I adopt the institutionalist premise that systems of delegation organize and structure European mass politics (Strøm 2000). Delegation systems mediate the exercise of political authority and the translation of public opinion into public policy. In delegation systems, decision-making authority is concentrated in the government. Lower levels in the chain of delegation-parliaments and voters-exercise influence through selecting decision-makers, and oversight and accountability. As we move from top to bottom in the delegation chain, formal means to influence policy and exercise accountability weaken. Whereas parliamentary parties still have some oversight instruments, voters only have the right to vote and, rarely, referendums. Moving from the bottom to the top of the chain, the ability of voters to shape policy through selecting elites also fades. Complex parliamentary negotiations lie between electoral outcomes and government-formation (Laver and Shepsle 1996). For these reasons, it is the norm to expect greater influence on policy outcomes of the preferences of actors at the top and fading influence along the chain of delegation. 
These general characteristics of delegation systems alone suggest that Eurosceptic politicization will influence EU outcomes the most if Eurosceptic parties reach government positions. Importantly, however, the EU further aggravates the weakness of lower-level actors in general and Eurosceptic parties in particular. Accordingly, Hodson and Puetter (2019, 1159-61) list many cases of Eurosceptic parties having less influence than their popularity or seat share. To begin with, pro-EU parties can more easily ignore voter preferences on European integration than other issues. Even though the EU matters increasingly in elections (de Vries 2007), voters rarely face a complete set of choices as parties from left to right do not all offer pro- and anti-EU positions. Instead, Eurosceptic positions tend to be offered by parties at the margins (Hooghe and Marks 2009). Eurosceptic voters need not find these parties appealing in left-right terms. Consequently, Euroscepticism has only been one among other and not the most important determinant of vote choice, reducing pressure on proEU parties to be responsive to Eurosceptic publics.

Moreover, the EU context also weakens the influence of parliamentary opposition parties. One source of influence of opposition parties is that they can try to form alternative governing coalitions by appealing to some governing parties to which they are ideologically closer. This can force other governing parties to shift policy so as not to jeopardize the coalition. However, in the EU context, most pro-EU parties have proven willing to exclude Eurosceptic parties from coalition consideration. Sometimes, Euroscepticism has been the reason, as in instances of government-formation during the Eurozone crisis (Schimmelfennig 2014). The exclusion of Eurosceptic parties might also be accidental as centrist parties have other policy reasons to refuse cooperation with parties at the margins or consider them not "responsible" enough for government roles (on government responsibility, see Bardi et al. 2014). If Eurosceptic opposition 
parties are mostly excluded from governing coalitions, they cannot credibly threaten to break up coalitions and thus cannot force governing parties to change policy. Importantly, however, the current centrist practice of excluding Eurosceptic parties is not without exception or set in stone. If it were to erode, Eurosceptic parties might find more coalition opportunities and be able to put greater pressure on governments.

Finally, the EU context weakens the ability of opposition parties to influence the government through parliamentary oversight and information rights. The EU introduces an additional arena of elite negotiations — intergovernmental bargaining —in which only governments participate while opposition parties and voters have to observe from the distance (Bergman 2000). By moving to the EU level, governments escape parliamentary oversight mechanisms that focus on the domestic arena. Many parliaments have implemented reforms to adapt to the EU but debate over the effectiveness of these reforms continues (Winzen 2017). Moreover, the low transparency of EU negotiations means that government responsibility for disliked outcomes is difficult to establish for opposition parties and voters (Hobolt and Tilley 2013). As a result, a key indirect mechanism by which opposition parties and voters influence policy in delegation systems - oversight and the threat of accountabilityworks less effectively in the EU context.

In conclusion, in any delegation system, it is to be expected that government policy depends, first and foremost, on government parties' preferences. It would be surprising if this were any different in the case of national demands for differentiated European integration. Moreover, the additional hurdles for opposition and electoral influence in the EU context suggest that voters and opposition parties might influence differentiated integration even less than other outcomes. What this means more generally is that, given the organization of European mass politics as systems of 
delegation, the impact of Eurosceptic politicization might be more uncertain and conditional than often assumed. Moreover, even if Eurosceptic parties govern, they still face the European-level constraints already identified in the literature.

\section{Data}

This study investigates the conditions under which intergovernmental conferences on new EU treaties conclude with opt-outs for individual member states, that is, differentiation. A differentiation formally lifts the legal validity of at least some rules of an EU policy regime for a given member state. The data encompasses all reforms of the EU treaties since the 1992 Maastricht Treaty. Since then, the EU has concluded eight further reform treaties. These include the comprehensive Amsterdam, Nice, and Lisbon Treaties and issue-specific treaties on the Schengen Area, the Pruem Convention, the European Stability Mechanism (ESM), the Treaty on Stability, Coordination and Governance (TSCG), and the Intergovernmental Agreement on the Single Resolution Fund (SRF). ${ }^{3}$

The analysis focuses on individual differentiation opportunities that arise from each of these treaties. During reform negotiations, governments revise one or several policy areas. In each area under negotiation, a government could demand a differentiation. Therefore, a policy area, negotiated in a treaty, constitutes a differentiation opportunity for a member states. The analysis only includes policies that were actually negotiated during a treaty reform (for an overview, see Table A2). All member states, multiplied by all policies negotiated in all treaties, gives the total number of observations. Data were obtained from the EUDIFF1 dataset on

\footnotetext{
${ }^{3}$ The appendix provides brief information on the issue-specific treaties.
} 
differentiation opportunities and instances of differentiation in EU treaty law (Schimmelfennig and Winzen 2014).

Previous research shows that that EU market, agricultural and regulatory policies have remained uniformly integrated in EU treaty law and become increasingly consolidated in secondary legislation. This study, therefore, focuses on member state opportunities to negotiate differentiation in core state policies. This is not to deny that, in the context of enlargement, member state exemptions follow a different logic. They encompass temporary discrimination that eases distributional conflicts (Plümper and Schneider 2007). Unlike reform treaties, enlargement negotiations do lead to differentiation outside of the area of core state policies. However, since enlargement treaties follow a distinct logic, they do not form part of this study.

On the side of the explanatory variables, this study is interested in Eurosceptic politicization at different steps of the chain of delegation: Among government parties, parliamentary opposition parties, parties outside the parliament, and the electorate. To measure Euroscepticism at these levels, I begin with party-level data from the Chapel Hill expert survey in which experts rank parties on a 1-7 scale of EU support (Bakker et al. 2015; Polk et al. 2017; Ray 1999). ${ }^{4}$ These data form the basis of several aggregate measures of Euroscepticism.

Beginning at the top of the delegation chain, government EU support is the seatweighted average of the positions on European integration of the governing parties. This is not the only possible conceptualization of government EU support. An alternative approach would be to focus on conflict within governing parties - that is, between the

\footnotetext{
${ }^{4}$ Chapel Hill data is not available for Croatia, Cyprus, Luxembourg, and Malta. In addition, the
} Czech government's position during the negotiation of the Lisbon Treaty cannot be identified as it had a non-partisan caretaker cabinet. 
leadership and rank-and-file members in parliament. The Chapel Hill surveys also ask experts to assess intra-party dissent. Government dissent is the extent to which governing parties are internally divided on European integration. This variable will be used as an alternative to government EU support.

Outside of the government, the analysis measures parliamentary opposition EU support as the seat-weighted support for European integration of the parliamentary opposition parties. In addition, an extra-parliamentary Eurosceptic party is said to be present if a party, while not holding parliamentary seats, has secured at least two percent of the vote in the most recent election and lies below the middle of the 1-7 EU support scale of the Chapel Hill expert survey.

Finally, the operationalization of popular Euroscepticism relies on a commonly used Eurobarometer item that asks citizens whether they think of membership as a "good thing", "a bad thing" or neither (Hobolt and de Vries 2016; Hooghe and Marks 2005). Euroscepticism is the share of respondents saying "a bad thing" minus "a good thing”. Larger values thus indicate stronger popular Euroscepticism.

---Table 1---

One might wonder whether these measures of Eurosceptic politicization correlate. Alternatively, they could also correlate negatively if the presence of a Eurosceptic party at one point of the delegation chain (e.g. in the extra-parliamentary arena) implied less Euroscepticism at other points (e.g. in parliament). However, Table 1 shows rather low correlations. By exception, Eurosceptic governing parties frequently suffer from conflicts between leaders and intra-party rebels. Otherwise, the low correlations suggest that it is feasible to ask which manifestations of politicization encourage differentiation outcomes in EU treaty negotiations. 
Some analyses below include control variables. First, ongoing differentiations are likely to increase a member state's propensity to obtain further differentiations in a policy area. For instance, a member state that opted out of the Eurozone provisions of the Maastricht Treaty almost automatically remains outside of subsequent reforms of the Eurozone. Second, the ratification of treaties in referendums has proven prone to the mobilization of Eurosceptic opposition. The appendix shows summary statistics (Table A1).

\section{Bivariate relationships}

Does government Euroscepticism drive differentiated integration or do opposition parties and voters matter as well? I begin exploring this issue on the basis of bivariate relationships between Euroscepticism and the use of differentiation opportunities by EU member states. A distinction will be made between the first 15 member states (EU15) and the countries that joined the Union after 2004 (Central and East European countries, Cyprus and Malta (CEEC)). The enlargement process of this group of young member states might have led to differentiation for reasons other than domestic politicization. Because of the effect of ongoing on new instances of differentiation, these enlargement outcomes might perpetuate in subsequent treaty reforms and conflate the results. For instance, the new member states were initially excluded from the Eurozone. Unless they adopted the common currency quickly, they did not participate in reforms of the Eurozone in the Lisbon, ESM and SRF treaties.

---Figure 1---

Consider government Euroscepticism first (Figure 1). When it comes to the EU15 countries, we observe that pro-EU governments rarely negotiate exemptions from 
EU treaties. This is also true of countries in which governing parties have managed to contain intra-party divisions. Clearly, however, the pattern is not perfect. It might depend on some influential outliers (notably Britain). Moreover, some countries that have had relatively Eurosceptic governments, such as Italy or the Netherlands, have not obtained corresponding national opt-outs. Figure 2 shows Euroscepticism beyond the governing parties. As regards opposition EU support and popular opposition to integration, we see plausible patterns, albeit slightly weaker than in case of government Euroscepticism. Here, too, we see potentially significant outliers and influential cases. At least in terms of the bivariate relationships, it seems least likely that there is any relationship between differentiated integration and the presence of extra-parliamentary Eurosceptic parties.

---Figure 2---

If we focus on the countries that joined the EU after 2004, the relationships appear similar at first sight. However, a closer look suggests that the CEE member states are rather divided into two groups. The frontrunners in terms of uniform integration are Estonia, Slovakia and Slovenia. These countries were the first to join the Eurozone after enlargement. Cyprus and Malta are not in this analysis due to missing data, but they belong to the frontrunner group as well. The remaining member states joined the Eurozone later, remained excluded from the free movement of workers and the Schengen area longer (especially Bulgaria and Romania), and maintained special rules for the free movement of capital and competition law. Poland also opted out of the Charter of Fundamental Rights. These examples indicate that the differentiation outcomes of the post-2004 member states are primarily shaped by the transitional provisions contained in their accession treaties rather than by Eurosceptic politicization. 
Yet, the Polish opt-out from the Charter of Fundamental Rights and the persistence of several relatively well-off countries outside of the Eurozone signals that some new members may be becoming similar to Eurosceptic old member states.

Overall, this first take suggests that government Euroscepticism relates most strongly to differentiated integration, although the tendencies in the cases of opposition and popular Euroscepticism point in the right direction as well. There is little to suggest that extra-parliamentary Eurosceptic parties matter for national opt-outs. Moreover, the evidence suggests strongly that pro-EU governing (and other) parties avoid differentiated integration entirely. When it comes to Eurosceptic governments, differentiation is more common, but there are countries that have had rather Eurosceptic governments and still remained uniformly integrated in the EU.

\section{Statistical analysis}

In order to further probe the aggregate patterns that we have seen so far, this section presents a multivariate analysis of the likelihood that a given member states realizes a differentiation opportunity by negotiating a national opt-out. The analysis includes a basic model, a model with additional control variables, and a multilevel model. Figure 3 summarizes the results of all three models and the appendix offers further technical considerations.

The basic model is a simple logistic regression of differentiation on the four measures of Euroscepticism. The results of this analysis are in line with the descriptive findings. The more governments support the EU, the less they are likely to opt-out of the Union's core state policies. There also is confirmation of the earlier impression that the patterns are less clear-cut when it comes to Euroscepticism beyond the government. These relationships are weaker and more uncertain in the statistical analysis as well. 
The next model adds measures of existing differentiation and ratification by referendum. The first of these two control variables displays the expected, strong relationship with national opt-outs. The relevance of referendums in turn appears more uncertain, partly owing to the fact that there have been few referendums overall. Adding these control variables does not warrant revising the conclusions regarding the measures of Euroscepticism—except, that the evidence that Euroscepticism beyond the government matters weakens further. The final model adds a multilevel structure to the analysis. A multilevel model can help account for the interdependence of observations within countries, policy areas, and treaties. For example, any given member state (e.g. Denmark) has many differentiation opportunities in a given treaty and over time. It is potentially problematic to pretend that these opportunities are fully independent of each other. However, despite this fact, the results from the multilevel model do not suggest different conclusions, except that the simpler models underestimate uncertainty.

---Figure 4---

Potentially, the observed relationship between government Euroscepticism and differentiated integration is very strong, as Figure 4 shows. There is a 40 percentage point difference in the probability that a highly Eurosceptic compared to a highly proEU government obtains a national opt-outs in EU treaty negotiations. However, the Figure also reinforces the impression from the descriptive analysis that this relationship is relatively uncertain and could be substantially larger or smaller. As we saw earlier, this is due to the fact that there are relatively few Eurosceptic governments in the first 
place and that not all of these governments necessarily produce differentiated integration.

The uncertainty around the results deserves further exploration. The descriptive analysis suggested that observations from selected countries, notably Britain, might have a strong bearing on the results. Figure 5 shows how removing individual member states from the analysis influences the findings for governmental EU support (panel a) and how excluding Britain in particular shapes all key results (panel b). The first insight is that, some variation notwithstanding, the basic finding is fairly robust. Taking out some countries with comparatively Eurosceptic governments and little differentiation, such as the Netherlands, strengthens the results, whereas removing some others weakens them. The UK proves most influential although, even in this case, the results tend to still point in the right direction. Moreover, what is most relevant for the question at hand is that government Euroscepticism shows the clearest relationship with differentiation compared to the other measures of Euroscepticism even after excluding British observations (see panel b). The other relationships are weak (opposition EU support), even more uncertain (extra-parliamentary Eurosceptic parties), or run in the wrong direction (popular Euroscepticism). Overall, it is inevitably the case that the results in an analysis with only few country groups vary with the inclusion or exclusion of individual countries. However, as this analysis covers all available countries, it is not possible to reduce this uncertainty by adding more data. The results thus show what we can learn and how certain we can be, given the available information, about the association of different forms of Euroscepticism and differentiation. They suggest that government Euroscepticism is more relevant that opposition, extra-parliamentary or popular Euroscepticism. 
The appendix includes analyses of additional issues that, for reasons of space, cannot be discussed in detail here. Two important questions are whether we should measure intra-party conflict over the EU rather than government Euroscepticism (Figure A2) and whether the results can be extended beyond the first 15 member states (Figure A3). We find little evidence to suggest the former and some support for the latter.

\section{Conclusion}

This study examined the relationship between the Eurosceptic politicization of the EU in the member states and differentiated European integration. Post-functionalist arguments suggest that demand for differentiation stems from domestic mass politics and Eurosceptic politicization (Hooghe and Marks 2009; Schimmelfennig et al. 2015). Scholars also highlight that functional and elite, European-level processes limit the impact of politicization. Rigid rules that make differentiated disintegration difficult to agree, externalities, and the technocratic nature of most EU competences seem to foster uniform integration even in adverse conditions (Hvidsten and Hovi 2014; Kölliker 2001; Schimmelfennig 2018).

In contrast to the literature's focus on European-level constraints, this study has examined which manifestations of Euroscepticism in domestic politics might lead to national opt-outs from EU treaties. Is government Euroscepticism decisive or do opposition parties and Eurosceptic electorates matter as well? This issue is left ambiguous in post-functionalist theory, which focuses on the contrast between the interest group and mass politics arenas. In this respect, theoretical perspectives that conceptualize domestic mass politics as systems of delegation (Strøm 2000)—and thus 
allow distinguishing various forms of Euroscepticism—provide an intuitive and complementary theoretical building block.

As a first step in exploring what post-functionalist theory can learn from a delegation perspective, this paper examined the intuitive expectation that Euroscepticism is only likely to affect differentiation if Eurosceptic actors reach government positions. In European countries, voters and parties at lower levels of the chain of delegation have only little direct policy influence and the European context exacerbates their weakness further. The delegation chain gives pro-EU parties the opportunity to contain Euroscepticism by downplaying EU issues in national elections and excluding Eurosceptics from governing coalitions. The result is that Eurosceptic actors often remain excluded from authoritative positions and less of a threat and reason to change policy for pro-EU parties than might seem at first sight (see also Hodson and Puetter 2019).

Regarding the effects of politicization on the EU- the theme of this volume - the results suggest caution. The findings are most consistent with the view that Euroscepticism needs to reach the government to matter. Indirect influence, such as pressure from Eurosceptic opposition parties, does not seem to suffice except, potentially, if it were to encourage governments to change their policy preferences (Meijers 2017). Even then, there are cases of Eurosceptic governments that do not negotiate opt-outs. It is conceivable that even Eurosceptic governments require additional motivation, such as from referendums, before they can overcome European incentives for uniform integration. If we think of countries such as the Netherlands, Italy, or recently Greece that have had relatively Eurosceptic governments at times, factors such as interdependence with the European economy, institutional lock-in in the Eurozone, or vulnerability towards global economic forces might influence whether 
Eurosceptic governments preserve uniform European integration. Factors such as these could explain variation among Eurosceptic governments and deserve more careful consideration than could be offered here. Clearly, however, pro-EU governments do not negotiate opt-outs in EU reform treaties.

The results differ from studies that indicate direct effects of public opinion on the EU (e.g., Hagemann et al. 2017; Koop et al. 2018; Bølstad 2015). Regarding this discrepancy, one could imagine that public opinion matters conditional on factors such as media attention. However, media attention can be taken as given in intergovernmental negotiations over core state policies—certainly compared to the attention that most EU laws and debates attract. Issue-characteristics could be another explanation. Possibly, governments are unwilling to set aside their beliefs in matters as fundamental as participation in the Eurozone, Schengen Area, or Area of Freedom, Security and Justice. Electoral incentives are a third candidate-explanation. Pro-EU governments might doubt that such significant opt-outs will have electoral net benefits. Certainly, the consequences would be clearer than in the case of individual laws or public statements, not only for Eurosceptic but also for pro-EU voters.

Appraising the results from a normative point of view, scholars have argued that a link between Euroscepticism and less integrationist outcomes is evidence of the responsiveness of the EU. However, this is not self-evident in the case of a salient and rather categorical outcome such as differentiation. It is not obvious that governments should pursue differentiation if their publics become somewhat more Eurosceptic. After all, given the available survey data, majorities in many countries remain in favor of integration even if Eurosceptic voters have become more vocal. In this light, it is also unclear whether more proactive accommodation of Euroscepticism-even if a minority position—would in fact avert threats to the Union's future or rather serve to alienate 
remaining supporters (cf. Hodson and Puetter 2019). This is a particularly pertinent issue because, unlike legislation or government rhetoric, which could be made somewhat more Eurosceptic, treaty opt-outs are a more rigid choice and shape a country's relation to the EU for decades. A case could be made that they should reflect majorities that prove able to win government office.

From an analytical perspective, this study encourages further attention to the conditions under which Euroscepticism matters. Referendums are a likely facilitating condition. Elite negotiations and low opposition influence are obstacles noted here, which could be tested further. More generally, it is likely that longer delegation chains and the absence of outside paths to policy change constrain the impact of Eurosceptic politicization. In particular, the translation of Euroscepticism into policy is likely to be weaker the more negotiated and secluded the parliamentary process is. In a similar vein, the more negotiated and bureaucratized ministerial negotiations are, the more difficult policy change becomes. Simply put, the more entrenched historically pro-integration government policy is along the delegation chain, the less the impact of Eurosceptic politicization.

\section{References}

Bailer, S., Mattila, M. and Schneider, G. (2015) 'Money Makes the EU Go Round: The Objective Foundations of Conflict in the Council of Ministers', JCMS: Journal of Common Market Studies 53(3): 437-456.

Bakker, Ryan, Erica Edwards, Liesbet Hooghe, Seth Jolly, Gary Marks, Jonathan Polk, Jan Rovny, Marco Steenbergen, and Milada Vachudova. 2015. “2014 Chapel Hill Expert Survey." University of North Carolina, Chapel Hill.

Bardi, L., Bartolini, S. and Trechsel, A. H. (2014) 'Responsive and Responsible? The 
Role of Parties in Twenty-First Century Politics', West European Politics 37(2): 235252.

Bergman, T. (2000) 'The European Union as the next step of delegation and accountability', European Journal of Political Research 37(3): 415-429.

Bølstad, J. (2015) 'Dynamics of European Integration: Public Opinion in the Core and Periphery', European Union Politics 16(1): 23-44.

de Vries, C. E. (2007) 'Sleeping Giant: Fact or Fairytale?: How European Integration Affects National Elections', European Union Politics 8(3): 363-385.

de Vries, C. E. and Edwards, E. E. (2009) 'Taking Europe To Its Extremes: Extremist Parties and Public Euroscepticism', Party Politics 15(1): 5-28.

de Vries, C. E. and Hobolt, S. B. (2012) 'When dimensions collide: The electoral success of issue entrepreneurs', European Union Politics 13(2): 246-268.

Genschel, P. and Jachtenfuchs, M. (2014) 'Introduction: Beyond Market Regulation. Analysing the European Integration of Core State Powers', in P. Genschel and M. Jachtenfuchs (eds). Beyond the Regulatory Polity? The European Integration of Core State Powers. Oxford: Oxford University Press, pp. 1-23.

Hagemann, S., Hobolt, S. B. and Wratil, C. (2017) 'Government Responsiveness in the European Union: Evidence From Council Voting', Comparative Political Studies 50(6): $850-876$.

Hobolt, S. B. and de Vries, C. E. (2016) 'Public Support for European Integration', Annual Review of Political Science 19(1): 413-432. 
Hobolt, S. B. and Tilley, J. (2013) 'Who’s in Charge?: How Voters Attribute Responsibility in the European Union', Comparative Political Studies 47(6): 795-819.

Hodson, D. and Puetter, U. (2019) 'The European Union in disequilibrium: new intergovernmentalism, postfunctionalism and integration theory in the post-Maastricht period', Journal of European Public Policy 26(8): 1153-1171.

Hooghe, L. and Marks, G. (2005) 'Calculation, Community and Cues: Public Opinion on European Integration', European Union Politics 6(4): 419-443.

Hooghe, L. and Marks, G. (2009) 'A Postfunctionalist Theory of European Integration: From Permissive Consensus to Constraining Dissensus', British Journal of Political Science 39(01): 1-23.

Hutter, S., Grande, E. and Kriesi, H. (2016) Politicising Europe. Integration and Mass Politics, Cambridge: Cambridge University Press.

Hvidsten, A. H. and Hovi, J. (2014) 'Why no twin-track Europe? Unity, discontent, and differentiation in European integration', European Union Politics 16(1): 3-22.

Kölliker, A. (2001) 'Bringing together or driving apart the union? Towards a theory of differentiated integration', West European Politics 24(4): 125-151.

Koop, C., Reh, C. and Bressanelli, E. (2018) 'When politics prevails: Parties, elections and loyalty in the European Parliament: Parties, Elections and Loyalty in the European Parliament', European Journal of Political Research 57(3): 563-586.

Laver, M. and Shepsle, K. A. (1996) Making and Breaking Governments, New York: Cambridge University Press. 
McElreath, R. (2015) Statistical Rethinking: A Bayesian Course with Examples in R and Stan, Boca Raton, FL: Chapman and Hall/CRC.

Meijers, M. J. (2017) 'Contagious Euroscepticism: The impact of Eurosceptic support on mainstream party positions on European integration', Party Politics 23(4): 413-423.

Plümper, T. and Schneider, C. J. (2007) 'Discriminatory European Union Membership and the Redistribution of Enlargement Gains', Journal of Conflict Resolution 51(4): $568-587$.

Polk, J. et al. (2017) 'Explaining the salience of anti-elitism and reducing political corruption for political parties in Europe with the 2014 Chapel Hill Expert Survey data', Research \& Politics 4(1): 2053168016686915.

Ray, L. (1999) 'Measuring party orientations towards European integration: Results from an expert survey', European Journal of Political Research 36(2): 283-306.

Schimmelfennig, F. (2014) 'European Integration in the Euro Crisis: The Limits of Postfunctionalism', Journal of European Integration 36(3): 321-337.

Schimmelfennig, F. (2016) 'Good governance and differentiated integration: Graded membership in the European Union', European Journal of Political Research.

Schimmelfennig, F. (2018) 'Brexit: differentiated disintegration in the European Union', Journal of European Public Policy 25(8): 1154-1173.

Schimmelfennig, F., Leuffen, D. and Rittberger, B. (2015) 'The European Union as a system of differentiated integration: interdependence, politicization and differentiation', Journal of European Public Policy 22(6): 764-782. 
Schimmelfennig, F. and Winzen, T. (2014) 'Instrumental and Constitutional

Differentiation in the European Union', Journal of Common Market Studies 52(2): 354370.

Strøm, K. (2000) 'Delegation and accountability in parliamentary democracies', European Journal of Political Research 37(3): 261-289.

Winzen, T. (2016) 'From capacity to sovereignty: Legislative politics and differentiated integration in the European Union', European Journal of Political Research 55(1): $100-119$.

Winzen, T. (2017) Constitutional preferences and parliamentary reform: Explaining national parliaments' adaptation to European integration, Oxford: Oxford University Press.

Winzen, T. and Schimmelfennig, F. (2016) 'Explaining differentiation in European Union treaties', European Union Politics 17(4): 616-637. 